\title{
Categorías y autoconciencia en Kant de Pedro Stepanenko
}

\author{
ISABEL CABRERA \\ Instituto de Investigaciones Filosóficas \\ Universidad Nacional Autónoma de México \\ misabel@servidor.unam.mx
}

\begin{abstract}
RESUMEN: Esta discusión pretende, por un lado, resaltar el valor heurístico de la interpretación de la deducción trascendental que propone Pedro Stepanenko en este libro y, por otro, cuestionar la precisión de algunas de sus conclusiones.
\end{abstract}

PALABRAS ClaVE: Kant, categorías, autoconciencia

Damos la bienvenida al libro de Pedro Stepanenko, Categorías y autoconciencia en Kant, que recién publicó el Instituto de Investigaciones Filosóficas de la unAm. Se trata de un texto serio y sumamente cuidadoso que pretende reconstruir uno de los argumentos más importantes y difíciles de la epistemología de Kant, a saber, la parte de la deducción trascendental de las categorías que se conoce como "la deducción subjetiva".

Antes de seguir, quisiera explicar, aunque sea brevemente, qué se entiende por "deducción trascendental de las categorías" y por "deducción subjetiva", y para ello me sirvo en gran parte del libro que comento: la "deducción trascendental de las categorías" es un argumento, o mejor, un conjunto de argumentos, que busca demostrar la legitimidad y necesidad de las categorías y su idea central es que ni el conocimiento ni la experiencia serían posibles si ésta última no estuviera estructurada y ordenada por un conjunto de reglas fijas o categorías. Así, dichas reglas tienen para Kant una doble función. Por un lado, en lo que se conoce como "deducción objetiva", cree haber demostrado que recurrir a un conjunto fijo de reglas generales hace posible la referencia a objetos, porque sólo así podemos asegurar el nexo entre la representación y su referente objetivo. Por otro lado, en lo que se conoce como "deducción subjetiva" Kant busca demostrar que sin categorías no podríamos tener experiencia, las categorías — como conjunto mínimo de reglas fijas- son requisito indispensable de la autoconciencia y sin autoconciencia no hay experiencia. El carácter fijo de las reglas permite hablar de una unidad general de la conciencia, de un "espacio" - y uso aquí una metáfora muy querida de Stepanenko— donde se da el juego de las representaciones. 
El texto conjuga un doble propósito. En sus primeros capítulos Stepanenko se pregunta por la génesis del argumento de la deducción subjetiva, cómo fue que Kant comenzó a pensar en ella y cómo fue paulatinamente adquiriendo importancia dentro del proyecto epistemológico general. El libro analiza meticulosa y pacientemente todos los textos precríticos - es decir, anteriores a la primera edición de la Crítica-y sigue de cerca la interpretación de Wolfgang Carl: está claro que se gestan dos objetivos, idealmente complementarios, que prefiguran la distinción entre ambas deducciones. El capítulo $\mathrm{V}$ —el más largo, el más ambicioso y el mejor logrado, desde mi punto de vista- abandona el interés histórico, la pregunta por los orígenes, y su propósito es, más bien, seguir el desarrollo de estos dos objetivos en la Crítica, haciendo hincapié en el segundo, para mostrar cómo es que resultan ser finalmente incompatibles: mientras el primer proyecto, el correspondiente a la deducción objetiva, supone la distinción entre representaciones que refieren a objetos y representaciones puramente subjetivas, el segundo proyecto, correspondiente a la deducción subjetiva, tiene por consecuencia que toda representación es resultado de la aplicación de categorías y, por consiguiente, es finalmente objetiva.

El valor de este capítulo no sólo está en su postura crítica sino también en su pertinencia heurística. Stepanenko ofrece una interpretación que nos permite no enredarnos, o al menos no enredarnos tanto, en el laberinto de la deducción trascendental. Alguna vez leí que Paton, un célebre comentarista de Kant, decía que la deducción trascendental era uno de los argumentos más difíciles que había producido el pensamiento filosófico occidental y que enfrentarse a él era como cruzar a pie el desierto del Sahara. El libro de Stepanenko nos ayuda a orientarnos y salir del atolladero conceptual al que se entra leyendo esos pasajes, y ello no es nada despreciable. La interpretación cuyo valor heurístico aquí destaco es una mezcla sagaz de cuatro ideas: 1) la conclusión de los primeros capítulos, según la cual hay dos propósitos en los textos precríticos que prefiguran la distinción entre deducción subjetiva y objetiva y que ayudan a establecerla, 2) la intuición comúnmente aceptada —y apoyada por el esquematismo— de que las categorías son básicamente reglas, 3) la idea de que las dos definiciones que ofrece Kant de las categorías, "como conceptos de un objeto en general" y como "funciones de síntesis" se corresponden con los propósitos de la deducción objetiva y la subjetiva respectivamente, y 4) la afirmación de que siempre que hay una referencia a la autoconciencia, estamos frente a la deducción subjetiva. Stepanenko propone releer la deducción teniendo estos elementos en mente, y preguntarnos frente a cada párrafo a cuál de los dos objetivos está contribuyendo lo que ahí se dice y... en efecto, las cosas se aclaran. Celebro y agradezco el valor heurístico de su interpretación. 
Quisiera ahora plantear al autor algunas inquietudes respecto a las conclusiones de su libro. La primera de ellas es una pregunta respecto a su afirmación de que los proyectos de ambas deducciones resultan incompatibles porque la deducción subjetiva condena toda representación a ser sintetizada por categorías y, por consiguiente, a ser finalmente objetiva, mientras que la deducción objetiva considera que las categorías sirven justamente para establecer la diferencia entre representaciones subjetivas y objetivas. Pero, ¿no ocurre acaso que las representaciones subjetivas, aquellas que no refieren a objetos externos, son de cualquier manera estados mentales que podemos adjudicar al sujeto empírico y en este sentido son objetivas? De hecho, una ciencia como la psicología que estudia al sujeto empírico podría hacer de dichas representaciones puramente subjetivas su objeto de estudio. Sospecho que esta es una dificultad que enfrenta la "deducción objetiva" no en función, sino independientemente de los resultados de la "deducción subjetiva".

La siguiente inquietud nos remite al primer apéndice del libro, donde el autor pone en el juego de las discusiones contemporáneas las conclusiones que logra su texto. Aquí se defiende, apoyando a Baum, que la deducción subjetiva no es un argumento regresivo sino progresivo, se construye el concepto - en este caso de autoconciencia - a partir de la noción de las categorías como funciones de síntesis. A mí me parece que la distinción entre argumento progresivo o sintético y argumento regresivo o analítico refiere, más que a dos tipos de argumentos, a dos maneras de reconstruir la argumentación. Creo que es posible siempre reordenar los argumentos de Kant de una u otra forma y que la manera más clara de hacerlo es la que usa el así llamado método analítico, que es lo que algunos solemos entender propiamente como argumento trascendental; en él, y cito a Kant (Prolegómenos, §5): "se parte de lo que se investiga como si fuese dado y se asciende a las condiciones solamente bajo las cuales se hace posible". Es cierto que en el caso de la deducción subjetiva — como argumenta Stepanenko- no se da por supuesto que la experiencia es un conocimiento de objetos, pero ello no implica que entre los presupuestos no se cuente ya con algún concepto de experiencia. Pienso que se parte de un concepto de experiencia más básico, la experiencia como un conjunto de representaciones relacionadas entre sí, y luego se procede a sacar a la luz las condiciones que hacen posible este concepto de experiencia. Resulta perfectamente posible - y más claro— reordenar el argumento de la deducción subjetiva a manera de un argumento regresivo y decir que lo que ahí se demuestra es que la experiencia, tomada como un conjunto de representaciones relacionadas entre sí, presupone la unidad de la conciencia y que a su vez ello no sería posible si no suponemos un conjunto fijo de reglas, categorías, o "funciones de síntesis". 
Por último, una pregunta en torno al concepto de autoconciencia que maneja Stepanenko, especialmente en el segundo de sus apéndices en el que se enfrenta a la interpretación de Strawson. Aquí, el autor confiesa que prefiere no interpretar la autoconciencia a la manera de Strawson, como autoadscripción de representaciones, sino como conciencia de las reglas o las funciones de síntesis. Me parece que esta concepción alternativa es atractiva pero no suficientemente clara. Stepanenko apela en varias ocasiones a la metáfora de un espacio donde se relacionan las representaciones, pero creo que hay que precisar más; sobre todo porque hacer depender un concepto tan central como es el de la autoconciencia, en las "funciones de síntesis" corre el peligro - que Strawson ya señaló- de entrar en las oscuridades de una especie de "psicología trascendental".

Dejo aquí mis preguntas y cierro mi comentario no sin antes volver a celebrar la aparición de este texto.

Recibido: 4 de junio de 2001 Aceptado: 25 de junio de 2001 